\title{
Relapse from Complete Response of Multiple Myeloma or Plasma Cell Leukemia
}

National Cancer Institute

\section{Source}

National Cancer Institute. Relapse from Complete Response of Multiple Myeloma or

Plasma Cell Leukemia. NCI Thesaurus. Code C70645.

Relapse from complete response of multiple myeloma or plasma cell leukemia requires one or more of the following: reappearance of serum or urine M-protein by immunofixation or electrophoresis; development of 5\% or more plasma cells in the bone marrow (relapse from complete response has a 5\% cutoff vs.10\% for other categories of relapse); appearance of any other sign of progression (e.g., new plasmacytoma, lytic bone lesion, hypercalcemia). Relapse requires two consecutive assessments made at any time before classification as relapse, and/or the institution of any new therapy. 